\title{
小児而性肺炎球菌性急性中耳炎の治療
}

\author{
長谷川賢作・松田＼cjkstart英賢*・硲田＼cjkstart猛真 \\ 竹内 裕美 $\cdot$ 北野 博也
}

\section{Treatment of Acute Otitis Media Caused by Penicillin Resistant Streptococcus Pneumoniae}

\author{
Kensaku Hasegawa, Takema Sakota, Hiromi Takeuchi and Hiroya Kitano \\ (Tottori University School of medicine) \\ Eiken Matsuda \\ (Yoka Public Hospital)
}

\begin{abstract}
The increase of infant cases of acute otitis media caused by penicillin resistant Streptococcus pneumoniae (PRSP) presents a formidable problem and has, in resent years, both hampered and prolonged medical treatment. From March 2001 to March 2002, we enforced a bacteriological examination aimed at germs of nasopharyngeal origin in an effort to identify the pathogen responsible for 292 cases of acute otitis media at our hospital. The detection frequency of PRSP was 93/292 (31. 8\%). The age of the patients ranged from three months to 61 years and $85(91.4 \%)$ were infants. In 70 of these 85 cases, we were able to achieve a good outcome. In this series, we examined the treatment progress in these 70 infant cases.

In 27 of these 70 cases (38.6\%), PRSP was detected alone. The simultaneously detected bacteria types were Haemophilus Influenzae (H.I) in 24 cases (34.3\%), Moraxella Catarrhalis (M.C) in 8 cases (11. $4 \%$ ) and H.I + M.C in 7 cases (10.0\%).

Although gender, the existence of mixed infections and the kind of antibiotics initially prescribed were not found to have had a significant effect on the outcome, both age and the existence of eardrum incision did appeared to influence the duration of the therapeutic period.
\end{abstract}

Key words : acute otitis media, penicillin resistant Streptococcus pneumoniae, antibiotics, eardrum incision, therapeutic period

\section{はじめに}

肺炎球菌は小児急性中耳炎の起炎菌の $40 \sim 50 \%$ を占 めるといわれている1). 近年, 耐性肺炎球菌を起炎菌と する小児急性中耳炎の増加が問題となり, 難治化・遷延 化を引き起こしている23). 急性中耳炎は, 生後 3 歳まで に $50 \sim 71 \%$ の小児が少なくとも 1 回は罹患する疾患で あり4)，市中病院における外来診療においてはありふれ
た疾患である. しかし，日常診療において治療に難渋す る症例が増えてきたため,われわれは 2000 年に発表され た保富ら5) の小児急性中耳炎治療に関するクライテリア に沿って，耐性肺炎球菌性急性中耳炎の治療を行ってき た. 本論文では，われわれの行ってきた治療の実態を評 価することを目的として，初診時に投与した抗生物質の 種類, 初診時年齢, 鼓膜切開の有無と治癒期間等につい 
て検討したので報告する.

\section{対象および方法}

対象は，2001 年 3 月から 2002 年 3 月までに公立八鹿 病院耳鼻咽喉科を受診した急性中耳炎の患者 292 症例で ある. 初診時にすべての急性中耳炎の患者より経鼻的に 上咽頭から擦過して採取した検体は, 輸送用媒地である Seed-swab ${ }^{\circledR} 2$ 号を用いて室温保存し, 同日の午後に中央 検查室で BTB 乳糖寒天培地, チョコレート寒天培地お よび羊血液寒天培地で $\mathrm{CO}_{2}$ を添加して純培養した. 純培 養後のコロニーの分離に際して, 肺炎球菌の同定には才 プソニンテストと胆汁酸テストを参考とした. 薬剤感受 性試験はマイクロスキャン社のMICroFAST $3 \mathrm{~J}^{\circledR}$ を使用し て, 微量液体希釈法に準じた方法で検討した，検体提出 後 $4 \sim 5$ 日で薬剤耐性試験の結果が得られ, 肺炎球菌の ペニシリンに対する最小発育阻止濃度をもとに，それぞ れの菌の耐性度を判定した。

耐性肺炎球菌が分離された小坚症例は, 84 症例, 85 検 体であった。このうち 1 症例は，急性中耳炎がほぼ治癒 した後に反復増悪した症例で, 延べ数としては 85 症例と なった。.今回は, 以下の項目について検討したので報告 する.

検討項目は, 混合感染の有無, 初診時投与抗生物質の 種類, 初診時投与抗生物質の投与日数, 投与量, 重傷度 別平均治癒期間, 初診時年齢, 性別, 鼓膜切開の有無々
治癒期間とした.

\section{結果}

2001 年 3 月から 2002 年 3 月までの間に急性中耳炎と 診断した症例で, 而性肺炎球菌が検出された小児症例は 85 症例で, 症例の内訳は男児 40 症例, 女児 45 症例, 平 均年齢 3.4 歳であった。症例の年齢分布は 3 力月から 9 歳であり，この年齢分布を図 1 亿示す．これらの小児症 例のうち急性中耳炎の治療完遂できた症例は 70 症例 (82 \%) であり，検討期間中に入院治療となった症例は 3 症 例であった。 よってわれわれは, 治癒までの経過が観察 できた 70 症例について以下の検討を行った。

上咽頭より耐性肺炎球菌と同時に検出された菌種はイ ンフルエンザ桿菌とモラキセラ菌であり, インフルエン ザ桿菌が同時に検出される傾向を認めるものの，これら の菌の検出率に偏りはなかった (図 2). また, 検出菌の 組み合わせや混合感染の有無による治癒期間への影響も 認めなかった。

而性肺炎球菌による小児急性中耳炎の 70 症例に, 初診 時投与した抗生物質を図 3 に示す. 主として用いた抗生 物質は, CPDX-PR, SBTPC, AMPC, CDTR-PI であった. 初診時に投与した抗生物質の平均投与期間は，5.5 日 (ペニシリン系 5.2 日, セフェム系 4.7 日) であり, 薬剤 感受性検查の結果によって必要な症例には薬剤を変更し た. 投与量についてみると, マクロライド少量投与例で

\section{症例数}

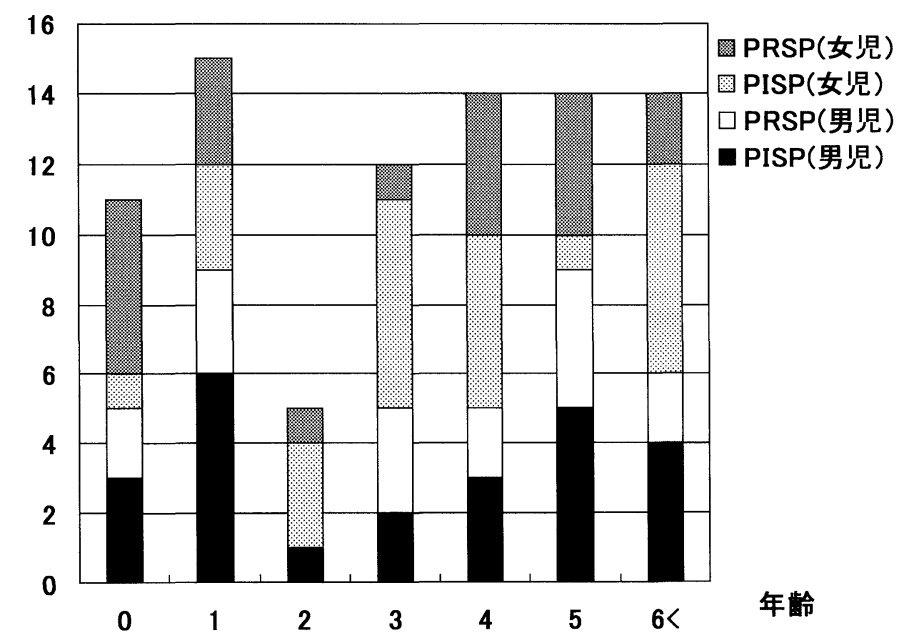

図 1 耐性肺炎球菌の年齢分布 PRSP : 高度耐性肺炎球菌 PISP : 中等度耐性肺炎球菌 


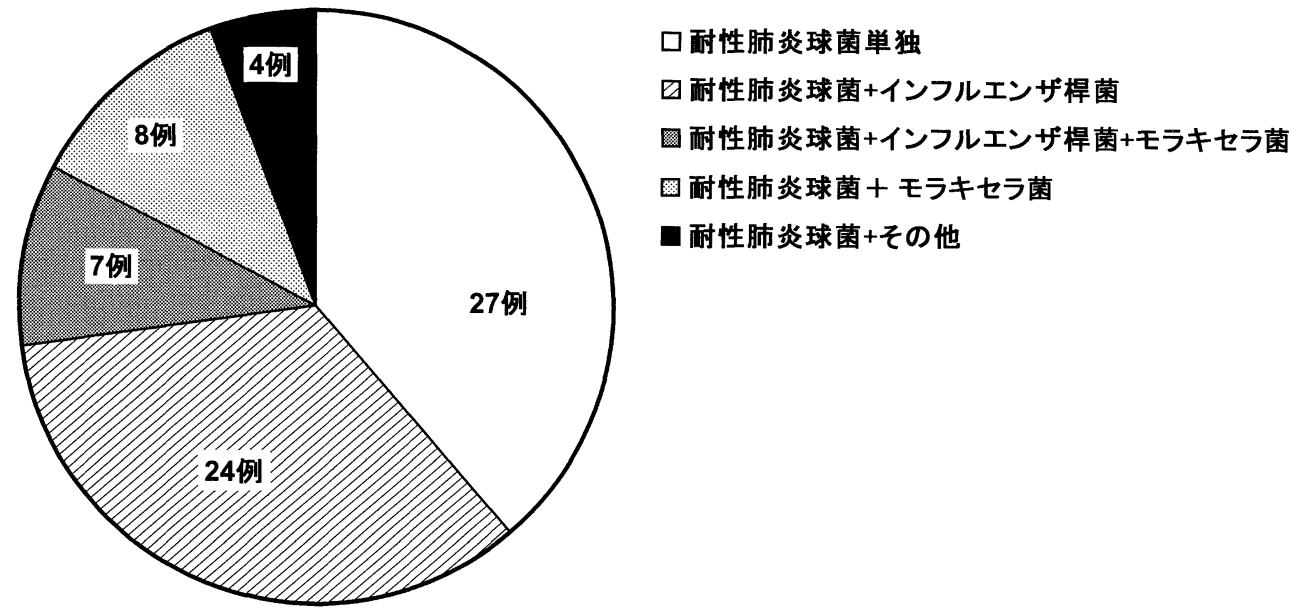

図 2 而性肺炎球菌と同時に検出された菌種

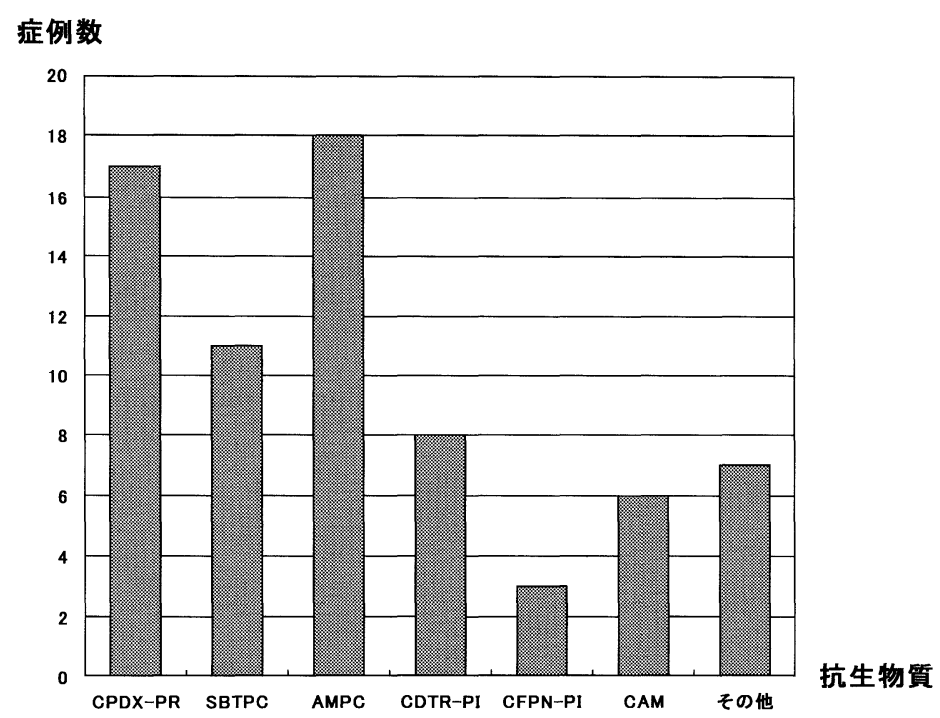

図 3 使用した抗生物質

CPDX-PR : セフポドキシム プロキセチル, SBTPC : スルタミシリン, AMPC : アモキシシリン, CDTR-PI : セフジトレン ピ ボキシル，CFPN-PI : セフカペン ピボキシル，CAM：クラリスロマイシン

は平均投与量は $5.2 \mathrm{mg} / \mathrm{kg}$ であり, セフェム系薬剤を使 用した症例のなかで, 4 症例のみが初診時から倍量投与 であった．検討期間中に複数回の菌検查を実施したもの は 4 症例であり，このらち明らかに菌交代を示したもの は 1 症例であった。

症例を重症度別に分けて, 初診時に投与した各種抗生 物質との関係を表 1 に示す。 また，これらの初診時投与 抗生物質に対する平均治癒期間を図 4 に示す. 軽症例に 分類される耐性肺炎球菌性急性中耳炎の場合には,
CDTR-PIやCFPN-PIを投与することで有意差は認められ ないものの治癒期間が短縮される傾向にあった (Student の $\mathrm{t}$ 検定, Wilcoxon の順位和検定).

初診時年齢と治癒期間について図 5 に示した. 初診時 1 歳以下の乳幼児群は，他の年齢群と比較して治癒期間 が短縮されていた (Dunnettの検定 $\alpha<0.05$ (両側)). 性別と治癒期間については, 有意差を認めなかった（表 2).

鼓膜切開は経過不良例や家族の了解の得られた 20/85 
表 1 重傷度別の初回投与楽剂

\begin{tabular}{c|c|c|c|c|c}
\hline \hline & CPDX-PR & SBTPC/AMPC & CDTR-PI/CFPN-PI & CAM & その他 \\
\hline 軽症 $(\mathrm{n}=25)$ & 5 & 8 & 4 & 5 & 3 \\
\hline 重症 $(\mathrm{n}=45)$ & 12 & 21 & 7 & 1 & 4
\end{tabular}

CPDX-PR : セフポドキシム プロキセチル, SBTPC : スルタミシリン, AMPC : アモキシシリン, CDTR-PI : セフジトレ

ン ピボキシル, CFPN-PI : セフカペン ピボキシル, CAM : クラリスロマイシン

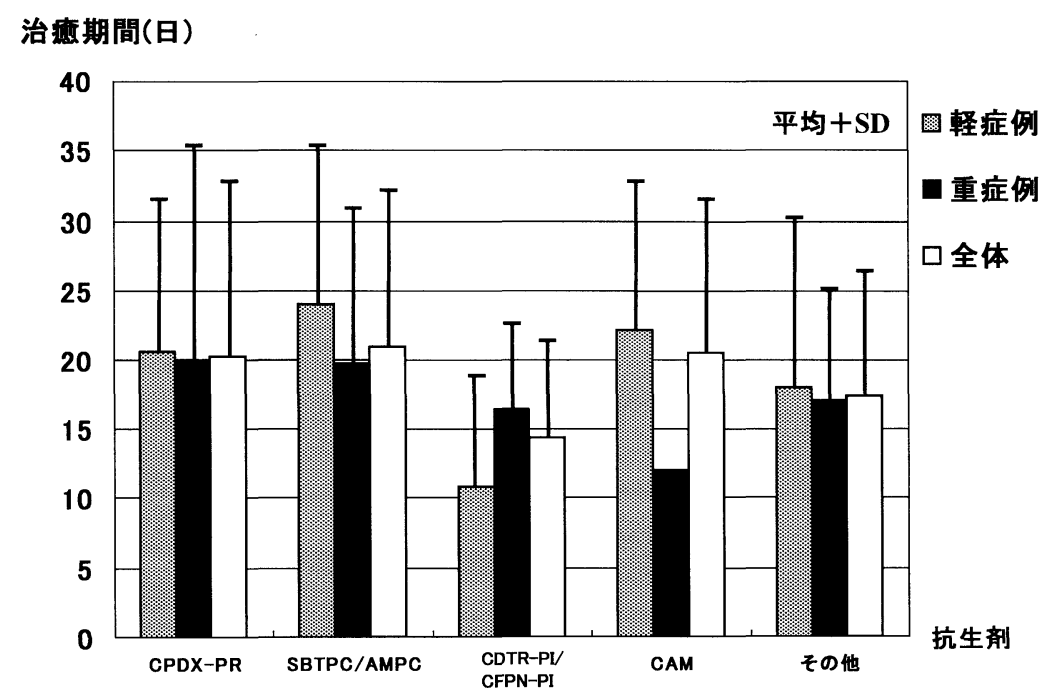

図 4 初回投与薬剂と治癒期間

CPDX-PR : セフポドキシム プロキセチル, SBTPC : スルタミシリン, AMPC : アモキシシリン, CDTR-PI : セフジレン ピ ボキシル, CFPN-PI : セフカペン ピボキシル, CAM : クラリスロマイシン

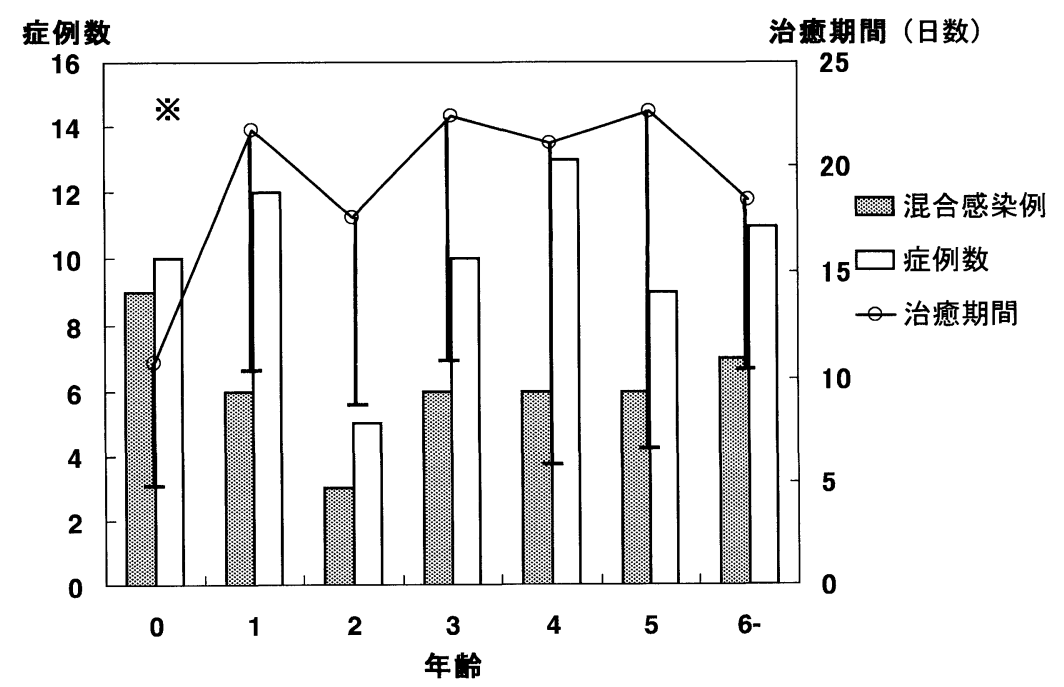

図 5 初診時年齢と治癒期間.

※初診時 1 歳以下の乳幼児群は, 他の年齢群と比較して有意に治癒期間が短縮されていた。 
表 2 性別と治癒期間

\begin{tabular}{c|c}
\hline & 治瘉期間 \\
\hline 男児 $(\mathrm{n}=29)$ & $19.7 \pm 13.0$ 日 \\
女児 $(\mathrm{n}=41)$ & $19.5 \pm 11.1$ 日
\end{tabular}

症例に施行した。鼓膜切開した時期と治癒期間について 治癒まで経過を観察できた 14 症例で検討した結果, 相関 係数 0.646 で, 鼓膜切開した時期と治癒期間とに有意な 相関関係を認めた（図 6, 回帰分析 $\mathrm{P}<0.01 ）$.

\section{考察}

近年ペニシリン而性肺炎球菌が急激に増加し, 耳鼻咽 喉科領域でも難治症例の統計的検討を行った報告が散見 されるようになってきた ${ }^{216)}$ 10). しかし，患者背景や薬 剂選択などの治癒期間に与える影響ついて検討した文献 は少ない，兵庫県の北部に位置する公立八鹿病院におけ る上咽頭からの耐性肺炎球菌の検出頻度は, 以前報告し た 1998 年 9 月から 2000 年 9 月までの検出頻度 ${ }^{11)}$ と比較 して，2001 年 3 月から 2002 年 3 月の 1 年間では $93 / 292$ 症例となり, 過去 3 年間に約 3 倍となっていた。これは, 1993 年に杉田ら ${ }^{7)}$ が報告した $24 \%$ を上回る検出頻度と なっている．比較的閉鎖的な医療圈を有するこの病院で も，耐性肺炎球菌の検出頻度が増加するに伴って外来治 療に抵抗する中耳炎が増加してきた。而性肺炎球菌によ る急性中耳炎は，もはや都市部だけの問題ではないよう
に思われる。

上咽頭より耐性肺炎球菌と同時に検出された菌種はイ ンフルエンザ桿菌とモラキセラ菌であり, インフルエン ザ桿菌が同時に検出される傾向を認めるものの，これら の菌の検出率に偏りはなかった. 坂本ら ${ }^{12)}$ はアデノイド と渗出性中耳炎に関する検討を行い，小児渗出性中耳炎 症例では, アデノイドにおける IgA 免疫応答が, 鼻咽腔 のインフルエンザ桿菌の定着に関与していると報告し た。インフルエンザ桿菌の上咽頭における定着が，急性 中耳炎の治療効果に何らかの影響を及ぼしている可能性 もあるが，今回の検討では検出菌の組み合わせや混合感 染の有無による治癒期間への影響を認めなかった。 保富 ら5) が 2000 年に急性中耳炎の治療指針を提唱し，われわ れもこれを参考として薬剤を決定してきた. 初診時投与 薬剤はアモキシシリンもしくはクラブラン酸アモキシシ リンとなっており，対象とした症例のなかで $29 / 70$ 例に ペニシリン系薬剤を使用した。初診時ペニシリン系薬剤 を投与した症例とセフェム系薬剤を投与した症例につい て重症度別に治癒と判断するまでの期間をみた場合に, 耐性肺炎球菌性急性中耳炎軽症例では, CDTR-PI, CFPNPI 投与により治癒期間を短縮できる傾向にあった．現時 点では初診時に起炎菌の推定が困難であり, 薬剤耐性を 誘導しない意味でも初診時にペニシリン系の薬剤を使用 しているが, 兄弟発症例など耐性肺炎球菌が起炎菌と推 定される場合には, CDTR-PI や CFPN-PI の通常量もし くは倍量投与をより早く行うことが望ましいと考える.

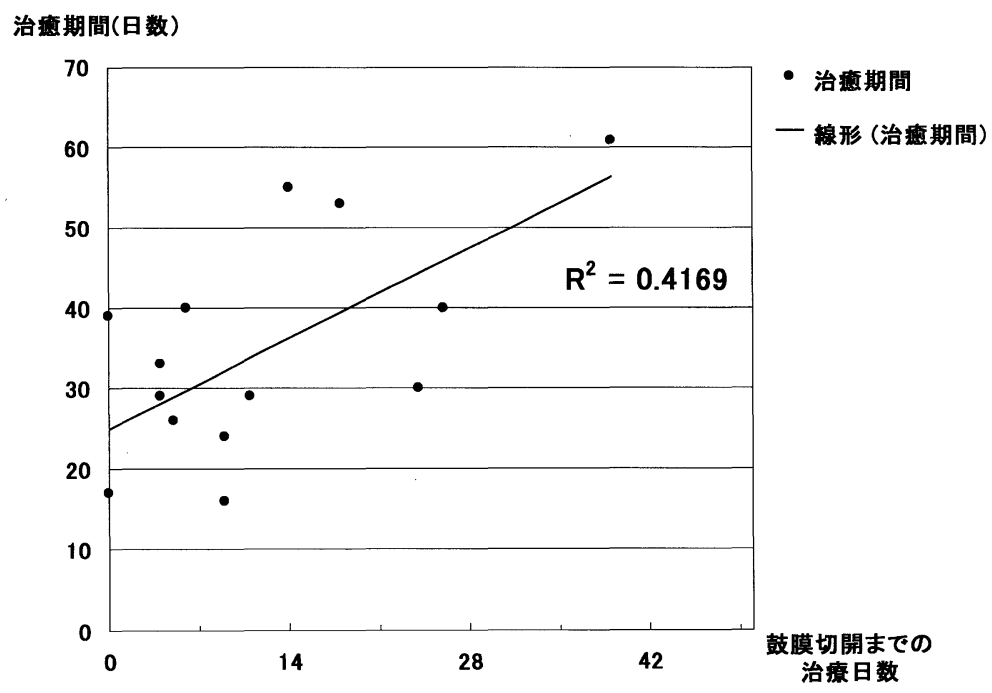

図 6 鼓膜切開の時期と治癒期間 
今回調査した細菌に対する薬剤感受性試験では，良好 な抗菌力を持つと考えられた薬剤を投与した症例でも治 癒期間が延長するものを認めた.これは,その患児の持っ ている細菌感染に対する免疫力が治療経過にかなり影響 しているものと考える. 山中 ${ }^{13)}$ 漠難治性反復性中耳炎患 児の免疫学的検討で, 難治性中耳炎や反復性中耳炎では 特定の細菌に対する抗体産生能が低下していることを示 唆した。 すなわち，この免疫異常は治癒期間を延長させ る要素となっていると考える.

初診時年齢と治癒期間については, 1 歳未満・ $1 \sim 3$ 歳· 3 歳以上に分類して検討することが多いようだが, 今 回はさらに細分化して検討した。 今回の調查では，1歳 未満の乳幼児とそれ以上の群で有意に治癒期間の相違を 認めた．伊藤ら ${ }^{14)}$ の報告によれば，近年集団保育が普及 し，そのために反復性中耳炎が増加しており，これらの 患児では耐性肺炎球菌への反復感染が影響していると述 べている. 今回の検討でも保育園入園後の 4 歳以上の小 児耐性肺炎球菌の検出率が高率であったことからも反復 接触が要因ではないかと推察する。

性別と治癒期間については 2000 年に宇野15) が臨床疫 学的検討をしたが，今回の調查においても性別による治 癒期間への影響汁認めなかった。

耐性肺炎球菌性急性中耳炎の治療期間は，経験上一般 細菌による急性中耳炎よりも長い傾向があると思われ， 今回の検討でも全体で平均約 19 日間を要した.この原因 を推定するため, 鼓膜切開の時期と治癒期間との相関関 係について鼓膜切開症例のなかで治療経過が明らかな14 症例について検討したところ, 鼓膜切開の時期が遅いほ ぞ治癒期間が延長していることがわかった。 近年抗生物 質の発達によって感染症治療に一定の効果をあげてきた が，耐性菌の検出頻度が増加するにつれて，早期の鼓膜 切開を勧める文献が増加している ${ }^{16) 17)}$. 今回の調査から も, 急性中耳炎の治療方法として単に薬物治療だけに頼 ることなく, 鼓膜切開術という外科的な手技をさらに積 極的に行ら必要があると考える.

初診時の細菌検査による薬剤感受性検査を行い, 適切 な抗生物質を投与することは感染症治療において当然重 要な治療指針であるが，さらに中耳における炎症を軽減 するために鼓膜切開を躊躇することなく早期に施行する ことが，難治性である耐性肺炎球菌による急性中耳炎治 療の大きな要素であると考える.

\section{まとめ}

近年耐性肺炎球菌による難治性急性中耳炎が増加して いる．これらの難治性急性中耳炎に対してより有効な治 療戦略を選択するために，初診時に細菌感受性試験を実 施し，適切な抗生物質を投与したうえで，早期の鼓膜切 開を実施することが重要であると考える，さらに治療に 抵抗して反復もしくは遷延化する症例に対しては，患児 の社会的背景や免疫学的素因にも検討を加える必要があ ると考える.

なお本論文の要旨は第 103 回日本耳鼻咽喉科学会総会（平成 14 年 5 月，東京）において報告した.

\section{参考文献}

1）末武光子:ペニシリン耐性肺炎球菌の現状と対策一PRSP 感 染症の現状と対策一. 日耳鼻感染誌 $18: 128 \sim 131,2000$.

2）遠藤廣子，末武光子，入間田美保子：入院加療を必要とし た乳幼児急性中耳炎, 下気道炎の検討一1994 1997 年, ペ ニシリン耐性肺炎球菌感染症の増加一. 化学療法 47:30 34, 1999.

3）赤上由美子, 小山 悟, 石塚洋一, 他 : 小児乳様突起炎 11 症例の検討. 耳展 $43: 43 \sim 48,2000$.

4) Teele DW, Klein JO and Rosner BA : Epidemiology of otitis media in children. Ann Otol Rhinol Laryngol 89 Suppl 68:5 6,1980 .

5）保富宗城，山中 昇：中耳炎のリスクファクターと治療ガ イドライン. 変貌する急性中耳炎一ペニシリン耐性肺炎球 菌性中耳炎の現状と対策（山中 昇編）. $169 \sim 185$ 頁，金 原出版，東京，2000.

6）杉田麟也，深本克彦，小栗豊子，他：1 歳未満の難治性急 性中耳炎. 日耳鼻感染誌 $8: 58 \sim 63,1990$.

7）杉田麟也, 出口浩一, 藤巻 豊, 他：急性中耳炎の原因菌 一ペニシリン低感受性肺炎球菌と反復性中耳炎の関係一. 日耳鼻感染誌 $12: 79 \sim 84,1994$.

8）末武光子, 入間田美保子：耐性肺炎球菌と急性中耳炎の重 症化一現実と対策一. JHONS 13:1147〜 1151，1997.

9）工藤典代，笹村佳美：乳幼児の急性乳様突起炎の臨床的検 討. 日耳鼻 $101 ： 1075 \sim 1081 ， 1998$.

10）宇野芳史：Penicillin 而性肺炎球菌による小児急性中耳炎の 臨床的, 細菌学的検討. 化学療法 $46: 396 \sim 403,1998$.

11）長谷川賢作，松田英賢，林 常夫，他：耐性肺炎球菌によ る急性中耳炎について. 耳鼻臨床 補 $106: 23,2001$.

12）坂本菜穂子, 黒野祐一, 螻川内英臣, 他：渗出性中耳炎患 者の鼻咽啌インフルエンザ菌に対するアデノイドの免疫応 答. 日耳鼻感染誌 $15: 48 \sim 51,1997$.

13）山中 昇: 反復性中耳炎. 図説耳鼻咽喉科 NEW APPROACH 
4. 耳鼻咽喉科疾患への免疫学的アプローチ（神崎 仁, 茂 木五郎編). $48 \sim 57$ 頁, メジカルビュー社, 東京, 1996.

14）伊藤真人, 白井明子, 窄中香織 $: 1$ 歳 6 力月児における鼻咽 腔ペニシリン耐性肺炎球菌の検出率. 耳展 $43: 540 \sim 560$, 2000.

15）宇野芳史:Penicillin resistant Streptococcus pneumoniae によ る小児急性中耳炎の検討一第 1 報：臨床疫学的検討一. 感 染症学雑誌 $74: 458 \sim 464,2000$.

16）小林俊光, 末武光子, 保富宗城, 他 : 反復性中耳炎の病態
と治療. 耳展 $42: 73 \sim 97,1999$.

17）杉田麟也：耐性肺炎球菌感染症の現状と治療上の問題点. 耳展 $42: 8 \sim 22,1999$.

原稿受付：平成14年10月 3 日

原稿採択 : 平成14年11月27日

別刷請求先 : 長谷川賢作

̄683-8504 米子市西町36番地の1

鳥取大学医学部附属病院感覚運動医学講座耳鼻咽喉・ 頭頸部外科学分野 